\title{
The Effect of the Monosubstituted Benzenes Functional Groups on the Inhibition of Methane Gas Biosynthesis
}

\author{
Kalombo Kayembe, Lolofo Basosila, Pius T. Mpiana*, Lisika Makambo, Pole C. Sikulisimwa, \\ Damien S. T. Tshibangu, Dorothée D. Tshilanda, Rigobertine K. Tati \\ Department of Chemistry, Faculty of Science, University of Kinshasa, Kinshasa, DR Congo \\ Email: "ptmpiana@yahoo.fr
}

Received September 22, 2012; revised October 26, 2012; accepted November 8, 2012

\begin{abstract}
Aromatic compounds are inhibitors of methane biosynthesis in anaerobic treatment of solid wastes and industrial effluents. Anaerobic treatment of solid wastes and industrial effluents may be limited by the methanogenic bacteria inhibition exerted by these types of compounds, the production of biogas is not possible and the organic matter contained in the effluent is not reduced. These effluents poured in the nature can be the basis of the pollution. The objective of this study is to evaluate the effect of monosubstituted aromatic compounds functional groups on the methanogenic inhibition. The toxicity to acetoclastic methanogenic bacteria has performed in serum flasks, utilizing digested pig manure as inoculums, by measuring methane production. The nature of aromatic functional groups was observed to have a profound effect on the toxicity of the monosubstituted aromatics. Among the monosubstituted aromatic, the chlorobenzene was the most toxic with $50 \%$ of inhibition occurring at the concentration of $30.08 \mathrm{mg} / \mathrm{l}$. In contrast, benzoic acid is the least inhibitory with $\mathrm{IC}_{50}$ of $2515.20 \mathrm{mg} / \mathrm{l}$. The partition coefficient octanol/water (logPoct), an indicator of hydrophobicity, had a significant correlation with the methanogenic toxicity.
\end{abstract}

Keywords: Monosubstituted Aromatics; Methane Gas; Biosynthesis; Inhibition; Digested Pig Manure

\section{Introduction}

Pollution of air and water by solid wastes as well as by industrial and agricultural effluents is increasing on the one hand, and on the other, the need for energy due to the large energy crisis caused by the sudden and rapid oil consumption is also increasing. All countries of the world are constantly looking for technological solutions allowing effective and less expensive treatment of these solid wastes as well as the industrial and agricultural effluents [1]. To cope with the energy crisis, they reduce their dependence to petroleum products and valuing other energy sources available to them $[1,2]$.

One of the technologies, enabling effective treatment of the organic fraction of the waste is methane fermentation also called "anaerobic digestion".

This technique not only solves the pollution problem, but it also produces methane used as energy source; the by-products of the treatment being used in agriculture as organic fertilizer. Thus, the biogas can be used to produce heat for cooking, drying or heating. It can also be used as fuel in operation of diesel engines, gasoline engines of vehicles and generators, etc. [3].

Experimental studies have shown that solid waste and

*Corresponding author. wastewater, especially industrial effluents may contain compounds that are toxic to methanogenic bacteria. These compounds are: oxidizing agents, volatile fatty acids, long chain fatty acids, antibiotics, ammonia, detergents, metal ions, and especially the aromatic compounds [1,4-6,7].

Anaerobic treatment of effluents may be limited by the methanogenic inhibition exerted by these types of compounds, not only the biogas production is not possible but the organic matter contained in the effluent is not reduced. In the nature, these effluents can be the basis of the pollution [5].

Aromatic compounds are naturally present in the environment as degradation products of lignin, tannins, phenolic amino acids, pigments and other aromatic compounds from plants. Human activity also contributes to the presence of aromatic compounds in the environment: waste incineration, petrochemical effluents, industries of paper manufacturing, pharmaceutical and chemical industries, pesticides etc. are, very important sources of aromatic pollution [7-9].

The presence of aromatic xenobiotic in the environment may create serious public health and environmental problems. Some aromatic compounds are mutagenic or carcinogenic and some may bioaccumulate. Additionally, synthetic aromatic compounds are often resistant to biodegradation 
and toxic to microorganisms [8].

Indeed, although the anaerobic biodegradability of aromatic compounds has been extensively studied, less attention has been given to the correlation structure of aromatic compounds and their toxic effects on the community of anaerobic bacteria.

Few works has published on the methanogenic toxicity in general and in particular, on aromatic compounds. Most of these works has performed with the granular sludge as inoculums from an industrial anaerobic reactor called “Upflow Anaerobic Sludge Bed” (UASB-reactor). In this work, digested pig manure from a laboratory scale digester is used.

The aim of this paper is to determine, the effect of monosubstituted aromatic compounds functional groups, on the inhibition of biogas biosynthesis.

\section{Materials and Methods}

\subsection{Biomass}

Pig manure from Kinduku Village of University of Kinshasa was digested in laboratory scale digester during about one year. The digested pig manure was used as inoculums in the anaerobic toxicity tests. The sludge (digested ping manure) was not previously acclimated to aromatic compounds.

Characteristic of inoculums is total suspended solid (TSS) concentration $85.90 \mathrm{~g} / \mathrm{l}$, volatile suspended solids (VSS) concentration $49.98 \mathrm{~g} / \mathrm{l}$, specific acetoclastic me-

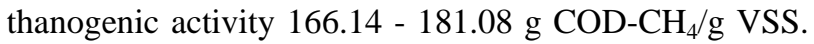
$\mathrm{d}\left(27^{\circ} \mathrm{C} \pm 1^{\circ} \mathrm{C}\right)$.

\subsection{Basal Medium}

The basal medium used in the anaerobic toxicity assay contained: $\mathrm{NaHCO}_{3}, 5000 \mathrm{mg} / \mathrm{l} ; \mathrm{NH}_{4} \mathrm{Cl}, 280 \mathrm{mg} / \mathrm{l}$; $\mathrm{CaCl}_{2} \cdot 2 \mathrm{H}_{2} \mathrm{O}, 10 \mathrm{mg} / \mathrm{l} ; \mathrm{K}_{2} \mathrm{HPO}_{4}, 250 \mathrm{mg} / \mathrm{l} ; \mathrm{MgSO}_{4} \cdot 7 \mathrm{H}_{2} \mathrm{O}$, $100 \mathrm{mg} / \mathrm{l}$; yeast extract, $100 \mathrm{mg} / \mathrm{l} ; \mathrm{H}_{3} \mathrm{BO}_{3}, 0.05 \mathrm{mg} / \mathrm{l}$; $\mathrm{FeCl}_{2} \cdot 4 \mathrm{H}_{2} \mathrm{O}, 2 \mathrm{mg} / \mathrm{l} ; \mathrm{ZnCl} 2,0.05 \mathrm{mg} / \mathrm{l} ; \mathrm{MnCl}_{2} \cdot 4 \mathrm{H}_{2} \mathrm{O}$, $0.05 \mathrm{mg} / \mathrm{l} ; \mathrm{CuCl}_{2} \cdot 2 \mathrm{H}_{2} \mathrm{O}, 0.03 \mathrm{mg} / \mathrm{l} ;\left(\mathrm{NH}_{4}\right) \mathrm{SeO}_{3} \cdot 5 \mathrm{H}_{2} \mathrm{O}$, $0.05 \mathrm{mg} / \mathrm{l} ; \mathrm{AlCl}_{3} 6 \mathrm{H}_{2} \mathrm{O}, 2 \mathrm{mg} / \mathrm{l} ; \mathrm{NiCl}_{2} \cdot 6 \mathrm{H}_{2} \mathrm{O}, 0.05 \mathrm{mg} / \mathrm{l}$; $\mathrm{Na}_{2} \mathrm{SeO}_{3} \cdot 5 \mathrm{H}_{2} \mathrm{O}, 0.1 \mathrm{mg} / \mathrm{l}$; EDTA, $1 \mathrm{mg} / \mathrm{l}$; resazurin, 0.2 $\mathrm{mg} / \mathrm{l}$; as well as $36 \% \mathrm{HCl}$ at $0.001 \mathrm{ml} / \mathrm{l}$, pH 7.2 [10,11].

\subsection{Aromatic Compounds}

The monofunctional aromatic compounds included: Cholorobenzene (Cbz), Toluene (Tol), benzene (Bz), Benzonitrile (Bnt), Phenol (Ph), Aniline (Anl) and Benzoic acid (Bac). All aromatic compounds were p.a. products.

\subsection{Anaerobic Toxicity Assay}

Specific acetoclastic methanogenic activity measurements were performed with $1 \mathrm{l}$ glass serum bottles sealed with butyl rubber septa. Digested pig manure 1.5 g volatile suspended solids per liter (VSS/l) have transferred into glass serum bottles containing $900 \mathrm{ml}$ of basal medium and acetate from a neutralized stock solution ( $\mathrm{pH} 7)$ to yield a final concentration of $4 \mathrm{~g}$ chemical oxygen demand per liter (COD)- $\mathrm{CH}_{3} \mathrm{COONa} / \mathrm{l}$.

The required quantity of inhibitory compounds was added to each flask to provide the toxic concentration to be investigated. No toxicant was added to the controls. The toxicant concentration was chosen to cause an inhibition of the acetoclastic activity ranging from $0-100 \%$ $[12,13]$.

The liquid was flushed with nitrogen gas for five minutes; and the flasks had sealed with rubber septum cap and placed in a reciprocating shaker at $27^{\circ} \mathrm{C} \pm 1^{\circ} \mathrm{C}$ (room temperature). The specific methanogenic activity was calculated from the slope of the cumulative methane production versus time curve and the quantity of VSS. The compound concentration that caused $50 \%$ of inhibition of the bacterial methanogenic activity had referred to as "IC 50 ". All specific methanogenic activity measurements were conducted in triplicate. The methanogenic activities of the control and samples containing inhibitory compounds were measured in order to determine the inhibition rate.

\subsection{Methane Gas Measurement}

The volume of methane gas produced was measured by serum bottle liquid displacement systems (Mariotte flask) as previously described [12-14].

\section{Results and Discussion}

\subsection{Inhibition of Specific Methanogenic Activity}

All concentrations of aromatic compounds examined exerted an inhibitory effect on the specific acetoclastic methanogenic activity. Figure 1 shows the inhibition of

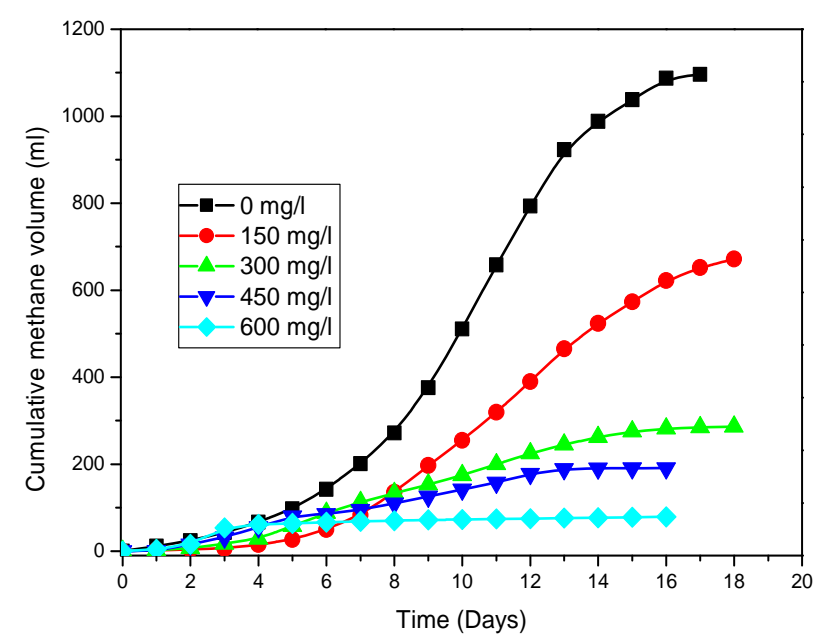

Figure 1. Influence of various concentrations of benzene on methane production. 
specific methanogenic activity at different benzene concentrations $(150,300,450,600$, and $750 \mathrm{mg} / \mathrm{l})$ used during the methanogenic toxicity assay. The $100 \%$ inhibition of specific methanogenic activity was caused at 750 $\mathrm{mg} / \mathrm{l}$ concentration of benzene.

Figure 2 shows the decrease in specific methanogenic activity with the increasing of the benzene concentration and illustrates the determination of $\mathrm{IC}_{50}$ values.

\subsection{Effect of the Functional Groups on the Methanogenic Toxicity}

The inhibitory effect of eight aromatic monosubstituted benzene compounds on the activity of acetoclastic methanogenic bacteria was evaluated in this study. The inhibition caused by each compound was tested at various levels, from concentrations that were nontoxic to those that were completely inhibitory to acetoclastic methanogenic activity, as seen in a typical experiment with benzene in Figure 2. Table 1 summarizes the $50 \%$ inhibiting concentrations $\left(\mathrm{IC}_{50}\right)$ of the aromatic compounds evaluated in this study, ranked in decreasing order of toxicity.

Table 1 shows that the least toxic compound was benzoic acid and chlorobenzene was the most toxic. The influence of the functional group on the methanogenic toxicity exhibited by monosubstituted benzenes is illustrated in Figure 3.

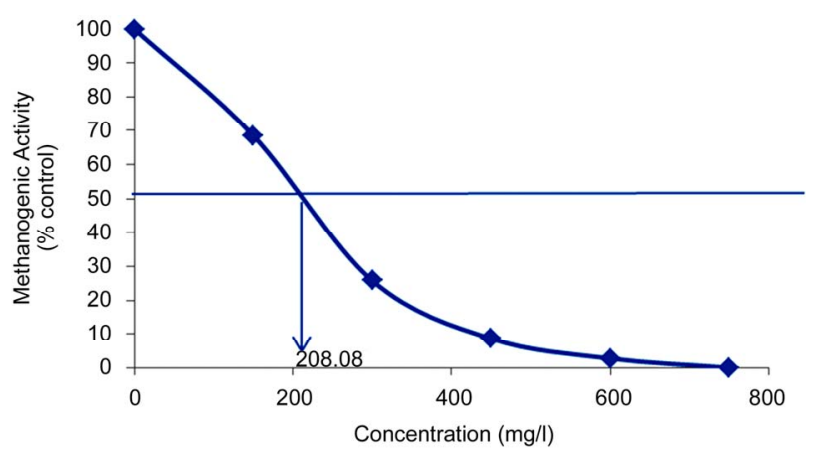

Figure 2. Methanogenic activity of digested pig manure exposed to benzene $(\mathrm{Bz})$ as a function of the benzene concentration and illustration of $\mathrm{IC}_{50}$ values determination.

Table 1. The $\mathrm{IC}_{50}$ values observed in the study for various monosubstituted aromatics.

\begin{tabular}{clccc}
\hline № & Compounds & $\mathbf{I C}_{\mathbf{5 0}}(\mathbf{m g} / \mathbf{l})$ & logPoct & $\begin{array}{c}\text { Molecular } \\
\text { weight }(\mathbf{g} / \mathbf{m o l})\end{array}$ \\
\hline 1 & Chlorobenzène & $30.08 \pm 2.01$ & 2.84 & 112.56 \\
2 & Toluene & $146.65 \pm 6.28$ & 2.73 & 92.14 \\
3 & Anisole & $168.80 \pm 5.31$ & 2.11 & 108.14 \\
4 & Benzene & $208.78 \pm 6.32$ & 2.13 & 78.10 \\
5 & Benzonitrile & $885.76 \pm 23.86$ & 1.56 & 103.12 \\
6 & Phenol & $1248.90 \pm 29.59$ & 1.46 & 94.11 \\
7 & Aniline & $1407.39 \pm 22.91$ & 0.90 & 93.13 \\
8 & Benzoïc Acid & $2515.20 \pm 32.83$ & 1.87 & 122.12 \\
\hline
\end{tabular}

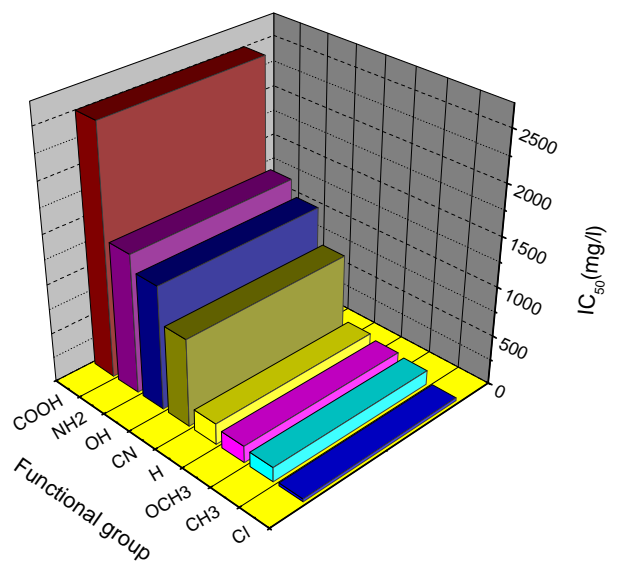

Figure 3. Variation of the methanogenic toxicity as a function of functional groups.

Figure 3 shows that the variation of the methanogenic toxicity of the monofunctional aromatic compounds is depending on the nature of the functional groups. Indeed, the nature of the functional group has a great influence on the methanogenic toxicity, the substitution of the benzene hydrogen on the aromatic ring by the following functional groups: $-\mathrm{Cl},-\mathrm{CH}_{3}$, and $-\mathrm{OCH}_{3}$ makes more toxic aromatic compounds while the substitution by: $\mathrm{CN}$, $-\mathrm{OH},-\mathrm{NH}_{2}$, and $-\mathrm{COOH}$ makes them less toxic.

The obtained results indicate that some general relationships exist between the aromatic structures and their inhibitory effects on methanogenic bacteria. According to the Figure 3, the toxicity of the monosubstituted benzenes increases in the following order:

$$
\mathrm{COOH}<\mathrm{NH}_{2}<\mathrm{OH}<\mathrm{CN}<\mathrm{H}<\mathrm{OCH}_{3}<\mathrm{CH}_{3}<\mathrm{Cl}
$$

These results are comparable to those obtained by Sierra and Lettinga $[8,10]$, except the benzene position in the toxicity sequence. Indeed, these authors found benzene $\mathrm{IC}_{50}$ of $1477 \mathrm{mg} / \mathrm{l}$ when in this work the value is $208.78 \mathrm{mg} / \mathrm{l}$. This difference could be due to the fact that different inoculums and temperatures were used.

\subsection{Correlation of the Methanogenic Toxicity with Aromatic Compounds Hydrophobicity}

Several studies have shown that there was an inverse correlation between toxicity and water solubility (hydrophilicity). This entails that there is a direct correlation between bacterial toxicity and hydrophobicity $[8,10,15]$.

To determine if the lipophilic character of tested aromatic compounds could be correlated with their methanogenic toxicity, the logarithm of the $\mathrm{IC}_{50}$ values of the monosubstituted aromatic compounds were plotted against the logarithm of the octanol-water partition coefficient $(\operatorname{logPoct})$ of the aromatic compounds. The study of toxicity-partition coefficient correlation was performed on seven monofunctional compounds with very close molecular weights: Chlorobenzene, Toluene, Anisole, Benzene, Benzonitrile, 
Phenol and Aniline. The Benzoic acid was not included in logPoct correlation because the carboxylic group dissociates at the assay $\mathrm{pH}$ of 7 .

A significant linear correlation was obtained $(\mathrm{r}=$ 0.93043) indicating that the partitioning of monosubstituted aromatics into lipophilic may have a role in the toxicity. Figure 4 shows the correlation line between the methanogenic toxicity and partition coefficient logPoct.

Hydrophobicity of a compound as indicated by logPoct has directly related to the partition of a compound into bacterial membrane. Compounds of great hydrophobicity are expected to accumulate more efficiently in membranes, causing a greater disturbance to the membrane structure and consequently, they would be responsible of high toxicity [10]

In fact, it is known that a substitution on the aromatic ring that enhances the hydrophobicity render the molecule more toxic and that enhances the hydrophobicity of aromatic ring causes the molecule to be less toxic. According to Hanch and Leo works [16]:

$>$ hydrocarbon or halogenated substituents on the benzene ring are lipophilic in the case of $\mathrm{CH}_{3}, \mathrm{~F}, \mathrm{Cl}, \mathrm{Br}, \mathrm{I}$, $\mathrm{NO}_{2}$.

The substituents containing electronegative atoms such as $\mathrm{O}$ and $\mathrm{N}$ are generally hydrophilic $\left(\mathrm{OH}, \mathrm{SH}, \mathrm{NH}_{2}\right.$, $\mathrm{CHO}, \mathrm{COOH}, \mathrm{CONH}_{2}, \mathrm{OCH}_{3}, \mathrm{OCOCH}_{3}$ ).

The diffusion of a molecule across a membrane depends on the permeability of the membrane. However, the membrane permeability is a function of the partition coefficient logPoct (hydrophobicity). So the more hydrophobic a molecule is, the higher is its membrane permeability and the greater is its toxicity $[17,18]$.

Indeed, a substitution on the aromatic ring which tends to make the molecule lipophilic (hydrophobic) increases

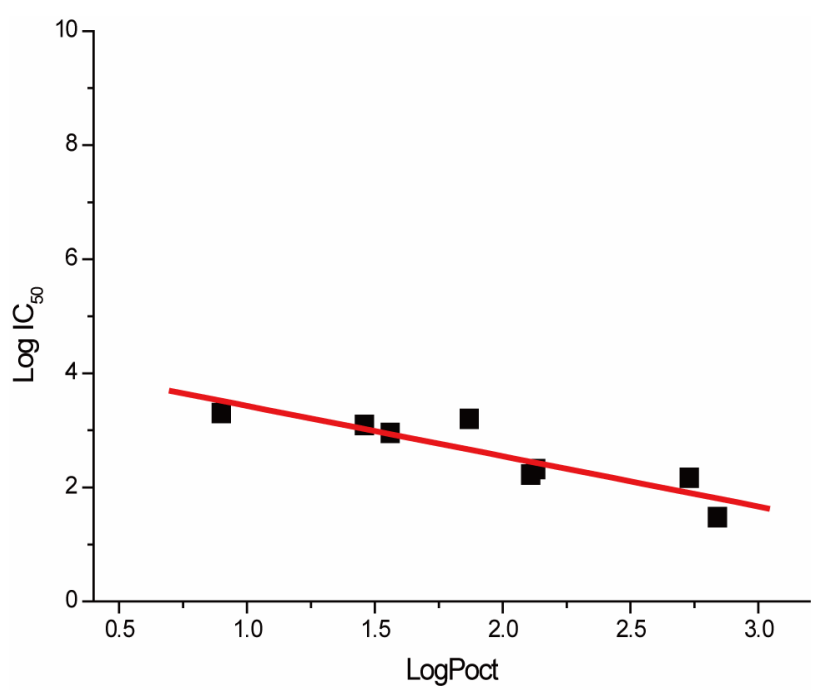

Figure 4. Effect of hydrophobicity on methanogenic toxicity: methanogenic toxicity $\left(\mathrm{IC}_{50}\right)$ and partition coefficient (logPoct) correlation. the affinity for membrane phase therefore the permeability of the membrane to this compound. The massive compound diffusion in methanogenic bacteria thus increases the toxicity for these microorganisms causing damage to subcellular components. This contributes to the decrease in methanogenic activity [8].

\section{Conclusions}

The obtained results indicate that some general relationships exist between the aromatic structures and their inhibitory effects on methanogenic bacteria. The toxicity of the monosubstituted benzenes increases in the following order:

$$
\mathrm{COOH}<\mathrm{NH}_{2}<\mathrm{OH}<\mathrm{CN}<\mathrm{H}<\mathrm{OCH}_{3}<\mathrm{CH}_{3}<\mathrm{Cl}
$$

The nature of the monosubstituted aromatic compounds functional groups, has a great influence on the methanogenic toxicity; the substitution of the benzene hydrogen on the aromatic ring by the hydrophobic functional groups like $\mathrm{CH}_{3}$, makes more toxic aromatics while the substitution by the lipophilic groups like $\mathrm{OH}$ makes aromatic compounds less toxic.

Hydrophobicity of a compound as indicated by logPoct has directly related to the partition of a compound into bacterial membrane. A significant correlation was obtained between monosubstituted aromatics toxicity $\left(\mathrm{IC}_{50}\right)$ and their hydrophobicity. So, the hydrophobicity is the most important parameter that explains the methanogenic toxicity, because cell membranes are nothing other than lipoproteins.

\section{REFERENCES}

[1] A. Saidi and B. Abada, "La Biométhanisation: Une Solution Pour Un Développement Durable,”Revue des Energies Renouvelables, CER'07, Oujda, 2007.

[2] K. Kayembe, "Production d'Energie par la Bioconversion des Déchets Agro-Industriels en Méthane,” Master’s Thesis, University of Kinshasa, Kinshasa, 1983.

[3] G. Lettinga and L. W. Hulshoff Pol, "Anaerobic Reactor Technology,” IHE-Delft \& WAU, Wageningen, 1990.

[4] K. Mbuyu and K. Kayembe, "Production du Méthane (Biogaz) par la Digestion Anaérobie des Drêches de Brasseries et des Lisiers de Vaches,"Revue Congolaise des sciences Nucléaires, Vol. 16, No. 2, 2000, pp 47-62.

[5] Y. Chen, J. J. Cheng and K. S. Creamer, "Inhibition of Anaerobic Digestion Process: A Review,” Bioresource Technology, Vol. 99, No. 10, 2008, pp. 4044-4064. doi:10.1016/j.biortech.2007.01.057

[6] H. H. P. Fang, "Inhibition of Bioactivity of UASB Biogranules by Electroplating Metals," Pure and Applied Chemistry, Vol. 69, No. 11, 1997, pp. 2426-2429. doi:10.1351/pac199769112425

[7] Y. Wang, Y. Zhang, J. Wang and L. Meng, "Effects of Volatile Fatty Acid Concentrations on Methane Yield and Methanogenic Bacteria,” Biomass and Bioenergy, Vol. 33, 
No. 5, 2009, pp. 848-853.

doi:10.1016/j.biombioe.2009.01.007

[8] R. Sierra and G. Lettinga., "The Role of Aromatic Structure on Methanogenic Toxicity," Medical Faculty Land Boww Rijks University of Gent (Belgium), Vol. 4, No. 4b, 1989, pp. 1437-1474

[9] C. Hecht and C. Greihl, "Investigation of the Accumulation of Aromatic Compounds during Biogas Production from Kitchen Waste,” Bioresource Technology, Vol. 100, No. 2, 2009, pp. 654-658.

doi:10.1016/j.biortech.2008.07.034

[10] B. A. Donlon, E. Razo-Flores, J. A. Field and G. Lettinga, "Toxicity of N-Substituted Aromatics to Acetoclastic Methanogenic Activity in Granular Sludge,” Applied and Environmental Microbiology, Vol. 61, No. 11, 1995, pp. 3889-3893.

[11] S. Kalyuzhnyi, V. Sklyar, T. Mosolova, I. Kucherenko, J. A. Russkova and N. Degtyaryova, "Methanogenic Biodegradation of Aromatic Amines," Water Science and Technology, Vol. 42, No. 5-6, 2000, pp. 370-383.

[12] J. Field and R. Sierra, "Waste Characteristics and Factors Affecting Reactor Performance," IHE-Delft \& WAU,
Wageningen, 1990.

[13] K. Mbuyu and K. Kayembe, "Etude de la Toxicité Méthanogénique des Cations $\mathrm{K}^{+}$et $\mathrm{Na}^{+}$,"Revue Congolaise des sciences Nucléaires, Vol. 16, No. 2.2000, pp. 65-76.

[14] N. Mambanzulua, K. Kayembe and V. Noki, "Détermination des Activités Méthanogènes Spécifiques des Lisiers dans le Traitement Anaérobique des Dechets.” Medical Faculty Land Boww Rijks University of Gent (Belgium), Vol. 64, No. 1, 1999, pp. 183-188.

[15] K. Kobayashi, "Metabolism of Pentachlophenol in Fish," Pesticide and Xenobiotic Metabolism in Aquatic Organisms, Vol. 99, 1979, pp. 131-143.

[16] J. Debord, “Coefficient de Partage,” 2012. http://www.unilim.fr/pages-peso

[17] P. T. Mpiana, “Biophysique Médicale,” Resud, Kinshasa, 2010.

[18] W. B. Whitman, T. Mothy, L. Bowen and D. R. Boone, “The Methanogenic Bacteria,” Prokaryotes, Vol. 3, 2006, pp. 165-208. doi:10.1007/0-387-30743-5_9 